\title{
The Misadventures of a Narrator and his Servant: Machado de Assis and the Characters of "A Semana".
}

The period immediately following the abolition of slavery (1888) and the end of the Brazilian Empire (1889), known as First Republic (1889-1930), was a time of intense and enormous modifications in Rio de Janeiro. Inspired by Haussmann's renovation of Paris, politicians and the elite intended to turn the city into a "modern" capital and a model for the whole country.

In this project, the habits and practices of the poor and working classes were seen as an obstacle and even a danger to both the public order and public health. The government considered the world of the so-called "dangerous classes" full of cultural practices - ways of living, dressing, working, having fun, healing etc. - that should be eradicated to pave the way to progress and civilization. The eradication efforts were implemented through repressive legislation, police surveillance and arbitrary and even violent coercive methods. According to Chalhoub, during the first republican administrations there were two fundamental points when it came to dealing with urban diversity: the poor classes were a threat, and the city could only be administered through technical and scientific criteria (Chalhoub, 2006, p.19). Scientific theories imported from Europe abounded, and the newspapers of the day often featured ideas ranging from criminalist theories to positivism to hygienist observations. 
The recurrence of these topics in the other columns of the Gazeta de Notícias, the newspaper where the crônicas were originally published, were pointed out by Machado de Assis. Highlighting the importance of the crônicas in Machado's work, John Gledson states that "A Semana" approaches an enormous variety of subjects and is not studied enough. Often, the texts have semi-hidden meanings which are seen only after a close reading and taking into account the historical context of those writings (Gledson, 2006, p.188-9). This article attempts to follow this procedure and focuses on crônicas narrated through the voice of a fictional narrator, whose commentaries on contemporary society are peppered by his interaction with his servant, José Rodrigues, who appeared in sixteen texts published between 1893 and 18961. The fictional narrator, with its recurring characteristics and particular background as an old man who fails to understand the present, shows Machado de Assis' conscious choice of establishing a fictional voice to his crônicas, making it, therefore, not possible to relate the opinions expressed in those texts directly to the writer. This is a common procedure featured in Machado's previous series of crônicas, such as "Balas de Estalo" (1883-6) and "Bons Dias!" (1888-9)².

One of the most remarkable characteristics of "A Semana"'s narrator was the contempt for what was regarded as a novelty, perceived at the time as a synonym of improvement, but seen in the series as a mask for old problems that superficial changes were trying to hide. The narrator often felt like a misfit within that new configuration, recalling the situation of other misfits in the attempt of modernization of the city, implemented without resolving basic issues such as housing and sanitation. The public

\footnotetext{
${ }^{1}$ In 1893 , six appearances (crônicas of 29/01; 12/02; 09/04; 27/08; 24/09; 12/11); in 1894 another eight (crônicas of $18 / 03 ; 06 / 05 ; 03 / 06 ; 12 / 08 ; 02 / 09 ; 16 / 09 ; 02 / 12 ; 23 / 12$ ) and one more in 24/03/1895 and the final one in 28/06/1896. I am including here the crônicas that mentioned the narrator's servant, even tough José Rodrigues' is not named.

${ }^{2}$ Those series of crônicas were published in the Gazeta de Notícias. For analysis of their narrators see Pereira, 2004 and Ramos, 2010.
}

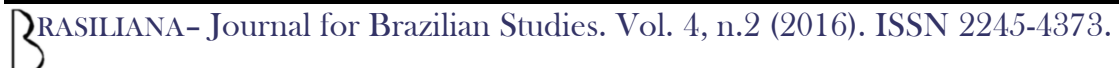


institutions barely followed the desired "modern" pace, one of the most notorious examples being the violent and arbitrary Rio police ${ }^{3}$.

Another major characteristic of the fictional figure was the alleged diversion from the main news to make room for marginal cases found in the press. The writer left small windows through which it was possible to see his criticism of the actual issues that captured the attention of the public. It was, therefore, a strategy to comment on what he pretended to ignore. The narrator reveals his approach when commenting on the act of writing (which itself was one of his recurring traits):

When I see one or two issues wishing to attract the public's attention, leaving others out in the cold, it gives me the desire to get behind the scenes, bringing into play only the small fry, the poor occurrences of nothing, the old anecdote, the casual slap, the theft, the anonymous stabbing, the mortuary statistics, the suicide attempts, the driver who flees, the news in short. For I am fair, and I cannot see the weak crushed by the strong. Also, I was born with some pride. I do not like facts or men imposing themselves. I abhor all sense of superiority. [...] The facts, I am the one who will declare them transcendent; men, I am the one who will call them extraordinary. (Assis, "A Semana", 10/07/1892)4.

\footnotetext{
${ }^{3}$ This and other narrator's characteristics are discussed with more details in: Cardozo de Souza,2015.

4 " $\mathrm{Eu}$, quando vejo um ou dois assuntos puxarem para si todo o cobertor da atenção pública, deixando os outros ao relento, dá-me vontade de os meter nos bastidores, trazendo à cena tão-somente a arraia-miúda, as pobres ocorrências de nada, a velha anedota, o sopapo casual, o furto, a facada anônima, a estatística mortuária, as tentativas de suicídio, o cocheiro que foge, o noticiário em suma. É que sou justo, e não posso ver o fraco esmagado pelo forte. Além disso, nasci com certo orgulho. Não gosto que os fatos nem os homens se imponham por si mesmos. Tenho horror a toda superioridade. [...] Os fatos, eu é que os hei de declarar transcendentes; os homens, eu é que os hei de aclamar extraordinários.". All crônicas quoted in this article were retrieved from the Gazeta de Notícias where they were originally published. All translations have been made by the author, unless otherwise noted, and the original texts are in the footnotes.
} 
Although, at first in this excerpt, the narrator tries to demonstrate that he based his choices on altruistic principles, it is clear he invested himself with the power of arbitration. It is his, and only his, the authority to choose which "occurrences of nothing" will be addressed in his column, following criteria that meet his expectations and private desires. His choice is confessed, proud, in nothing modest 5 .

Moreover, another recurrent theme in "A Semana" is the aversion to progress, especially the ostentation of scientific arguments. The position adopted by the narrator reflects Machado's perception about the period. He noticed that journalistic writing was mixed with medical and police terms, creating texts that deviated farther and farther from what he considered good literature. This is related to the already mentioned feeling of inadequacy of the narrator towards the present as well as his constant comparison of current events to the past, as we can see in the following fragment:

Everything is over. Eclipses, comets, dreams, victims' guts, number thirteen, left foot, how many chapters have been torn from the human soul, to have them replaced by others, exact and true, but deeply insipid. [...] Calculations have replaced the novelty, foretelling has killed surprise (Assis, "A Semana”, 16/04/1893).

\footnotetext{
${ }^{5}$ Betella points out that some of the crônicas of "A Semana" gain the added feature of a sort of "theme" that is repeated during the narrative, reinforcing the "ideological background" of someone who is detached and not interested in what is at stake, yet always has the last (and right) word.. See Betella, 2007, p.185.

6 "Tudo acabou. Eclipses, cometas, sonhos, entranhas de vítimas, número treze, pé esquerdo, quantos capítulos rasgaram à alma humana, para substituí-los por outros, exatos e verdadeiros, mas profundamente insípidos. [...] $\mathrm{O}$ cálculo substituiu a novidade, o anúncio matou o espanto."
} 


\section{José Rodrigues: servant and reader.}

"A Semana" presents another fictional character: José Rodrigues, whom the narrator claims to be his servant. Rodrigues' first appearance was in the crônica of January 1893, which put tradition and progress in opposition. The text points out the brutality in the actions of the health and police authorities whose most recent example was the destruction of the tenement house Cabeça de Porco. According to the narrator, this kind of transformation was eliminating Rio de Janeiro's charm and making the city unrecognizable. The ideal embraced by the government affected citizens' lives since they felt compelled to follow "the Rua do Ouvidor way, where we walk and where life is buzzing every day and every hour. Modern topics abound" (Assis, "A Semana", 29/01/1893)7. One of the modern issues was the exaggerated emission of debentures:

A servant of mine, who lost everything he owned purchasing misadventures... forgive him; he is a poor man who speaks poorly. I taught him the correct pronunciation of debentures, but he told me that is what they were misfortunes, mishaps and the work of rascals. For this servant also defends the capital; the difference is he does not accuse himself of attacking others, but others of having taken his (Assis, "A Semana", 29/01/1893). ${ }^{8}$

\footnotetext{
7 "à maneira da Rua do Ouvidor, que pisamos, onde a vida passa em burburinho de todos os dias e de cada hora. Chovem assuntos modernos." About the Rua do Ouvidor, see: Gerson, 2000, p.42-51.

8 "Um criado meu, que perdeu tudo o que possuía na compra de desventuras... perdoem-lhe; é um pobre homem que fala mal. Ensinei-lhe a correta pronúncia de debêntures, mas ele disse-me que desventuras é o que eram, desventuras e patifarias. Pois esse criado também defende o capital; a diferença é que não acusa a si de atacar o dos outros, e sim os outros de lhe terem levado o seu.”.
} 
In this passage, the writer uses what could be considered a formula in "A Semana": he mentions several issues, apparently disconnected, that would be tied just at the end of the text. Although it is the opposite of what the narrator says, the suggestion the excerpt conveys is that José Rodrigues understands the situation better than his boss. While the employer considered Rodrigues a poor man who "speaks poorly", the servant translates into a single word the whole scenery that surrounds them: misadventures. This situation reflects not just the debentures case, but the whole apparatus that prevents him from getting his money back or from seeking revenge against those who harmed him. If we have in mind the other misadventures mentioned in the crônica - such as the demolition of the Cabeça de Porco - we can cogitate Machado is showing us, through the fictional narrator's speech, the flip side of progress.

In the same crônica, the narrator asserts: "This man reads everything published in the newspapers. He was the one who told me about the new complaint against the [Companhia] Geral'; he calls it new, I do not know if there was another" (Assis, "A Semana", 29/01/1893) ${ }^{10}$. José Rodrigues is presented as a reader. It is known that "A Semana" deals mostly with news published in the daily papers, including others than Gazeta de Notícias, ranging from little notes to big headlines ${ }^{11}$. By saying his servant is the

\footnotetext{
${ }^{9}$ The Companhia Geral was involved in the scandals related to the Encilhamento, "an extraordinary boom and subsequent catastrophic fall of the stock market, accompanied by unprecedented levels of negligence in issuing currency, partial payment of shares and debentures and simple corruption ..." [“extraordinário boom e subsequente queda catastrófica do mercado de valores, acompanhado de inauditos níveis de negligência na emissão de papel moeda, pagamento parcial de ações e debêntures e simples corrupção...”] Gledson, John, in: Assis, 1996, p.19.

10 "Lê tudo o que os jornais publicam, este homem. Foi ele quem me deu notícia da nova denúncia contra a Geral; ele chama de nova, não sei se houve outra."

${ }^{11}$ According to John Gledson, Machado mentioned, only in the two first years of "A Semana", seven other newspapers: Jornal do Commercio, Diário de Notícias, O Paiz, O Tempo, Jornal do Brasil, Cidade do Rio e Rio News. Cf. Gledson, in: Assis, 1996, p.29.
} 
one who reads the newspapers, the narrator reinforces the idea that he is not interested in the reported events, which is also present when he just procedurally lists them or says they bored him. It could also be an attempt to create other points of view about the facts mentioned in the text since there are two distinguished fictional voices, and they have diametrically opposed social positions. Their different readings of the events reflect their social condition: if the boss reads newspapers with indifference, distraction or even does not read them at all, José Rodrigues reads them looking for news that directly affect him.

The class opposition existent in the relationship between employer and employee defines their interests, their readings, and their languages. This is what also happens in a crônica that brings up the discussion about a housework regulatory project, when the narrator argues that since he is not the one negatively affected by its creation - he was not the one who had the "misfortune" of serving - he wishes for the approval of the law: "In what concerns me, [the law] will not be met, for I have not come to the world to fulfill the law just because it is the law. If it is law, it had better come with a stick; otherwise it is nothing" (Assis, "A Semana", 09/04/1893)12. José Rodrigues' name is not alluded to in this text, but we can perceive the similarity between these thoughts and the statements of the boss about his employee during the series. The servant is now used as a basis for reflection on labor relations at the time. It is implied that the law would not be fulfilled, or would be fulfilled only partially as it suited the employers' interests. The narrator takes the bosses' side and reveals that even if laws that benefit the servants were formulated, they would not be put in practice. Therefore, the legislation became a

12 "Na parte em que me constrange, não será cumprido, porque eu não vim ao mundo para cumprir lei, só porque é lei. Se é lei, traga um pau; se não traz um pau, não é nada." 
mere rhetorical ornament. Moreover, the semanista ${ }^{13}$ appears to reproach the government's attempt to intervene in the employer-employee relationships.

After a hiatus of months, the character returns to the series and gains his own contours: "I opened my eyes, saw my servant José Rodrigues standing by my side - that same ignorant man who translated debentures as misadventures. In the end, a good man; little intellectual sufficiency, but a soul... He gave me water and stayed with me telling happy stories until I fell asleep" (Assis, "A Semana", 27/08/1893)14. For the narrator-boss, his servant, although being a helpful and dedicated man, is ignorant and stupid. According to this view, it is Rodrigues' kindness and docility that make of him an easy target for exploitation. Another interesting point in this text is the cronista's attempt to remind the readership of his servant's existence, and this time he becomes a recurring presence. This procedure implies the existence of regular readers of "A Semana", and the repetition of characteristics reinforces the hypothesis of a fictional narrator.

José Rodrigues' appearances usually occur when the narrator is waking up from dreams and reveries. Sometimes, he comes to be part of the master's illusion, as in the case in which the narrator - after confessing his mixture of laziness and fear while listening to the Revolta da Armada ${ }^{15}$ gunfires - is reading Homer and imagining himself as one of the Iliad characters. The servant offers him a refreshment and, in the fantasy, inflates his ego, saying: "You are already a god, you're in Olympus, next to Jupiter"

\footnotetext{
${ }^{13}$ In this article, semanista is used as a synonym for narrator. The word is used by the narrator himself in "A Semana".

14 “Abri os olhos, vi ao pé da cama meu criado José Rodrigues - aquele mesmo ignaro que traduzira debêntures por desventuras. Ao cabo, um bom homem; pouca suficiência intelectual, mas uma alma... Deu-me água e ficou ao pé de mim, contando-me histórias alegres, até que adormeci."

${ }^{15}$ The Revolta da Armada [Brazilian Naval Revolts] occurred between 1893 and 1894. Part of the Brazilian Navy rebelled against President Floriano Peixoto's acts.
} 
(Assis, "A Semana", 18/03/1894)16. In the dream, the narrator confuses Rodrigues with the goddess Hebe, who, according to the Greek mythology, is linked to housework, playing the role of a maid in her family ${ }^{17}$. Therefore, even when the employee is "elevated" to the Olympus, he is still a servant, submissive and almost worshiping his employer.

Three months later, it is literature that leads to dreams again in another crônica. While reading newspapers, just before going to bed, the narrator affirms: "Morning news, read at night, always produce the effect of old songs, from which I conclude that the gazettes are most charming at the time that they appear." Bored with newspapers, he leaves them for Hamlet and starts to dream he was the main character of Shakespeare's book while José Rodrigues becomes Horatio. The illusion is interrupted by the servant: “Wake up, boss! Wake up!” (Assis, “A Semana”, 03/06/1894)18.

Rodrigues is the one who symbolically brings his master back to reality, even if this procedure irritates the narrator. It is the servant who, through his immediate concerns - usually related to finances or health - seems more attached to the context that surrounds them. The employee always reads the newspapers, marking one more time his closer and more attentive relationship with the events than his master-dreamer. His connection with reading takes place by examining the papers and also by the literary characters embodied by him.

It is noteworthy that José Rodrigues takes charge of a task that should be of the cronista, that is, reviewing the week's events reported by the press. The "outsourcing" of

\footnotetext{
16 “Tu és já um deus, tu estás no próprio Olimpo, ao lado de Júpiter."

${ }^{17}$ Cf. Grimal, 2005 [1951], p.193.

18 "Notícias da manhã, lidas à noite, produzem sempre o efeito de modas velhas, donde concluo que o melhor encanto das gazetas está na hora em que aparecem." / "Acorde, patrão! Acorde!"
} 
his obligation brings us to a very noticeable facet of the relationship between the two characters in "A Semana": the narrator repeatedly reinforces his superior condition compared to that of his employee, who always appears as the exploited, the deceived, the naive. This caricatured description points to the logic of dominant and dominated in the late nineteenth society, which, at first sight, does not seem to differ much from the Empire. However, we cannot stop here.

In her analysis of Rodrigues' appearances in "A Semana", Lima argues the character complies, in most cases, with the traditional role of the servant in comedy. She adds that he "not only steals the show in some of the crônicas, but also, so to speak, steals the boss's voice (and even his ideas), establishing a relationship with him that lead us to think of a small dialectic of master and slave" (Lima, 2012, p.129) ${ }^{19}$. I believe the writer was, indeed, discussing social class issues through the fictional servant; nevertheless, he did not demarcate mere continuities, but pointed to the fallibility of the supposed logic of those in power. We must bear in mind that it is an admittedly selfish and smug boss who narrates the events. Even when a dialog is presented to us, we have a narrator who constantly tries, to emphasize his superiority. In between the lines of the crônica, it is José Rodrigues who demonstrates smartness, who pays attention to both the narrative and theoretical incoherences in the journalistic texts. Meanwhile, his employer holds on to his pride, trying to include himself in the flawed logic of those who write those arguments, even though he did not understand them.

It is not the servant who steals ideas from his employer, but the opposite. The narrator frequently uses Rodrigues' knowledge, even though he allegedly despises it. As in the first crônica that mentions the employee, when we see that the word

\footnotetext{
19،“[Rodrigues] não só rouba a cena em algumas das crônicas em que aparece, mas também, por assim dizer, rouba a voz do patrão (e até mesmo suas ideias), instaurando com este uma relação de tal ordem que nos levar a pensar em uma pequena dialética do senhor e do escravo." [emphasis in the original].
} 
misadventures better translates the situation, the semanista resorts to José Rodrigues when he conjectures about the losses the tram companies were making because of the supposed dishonesty of their drivers:

[...] The interest is more constant. José Rodrigues, whom I consulted on this matter, told me that losing is part of the job; the company whose debentures he owned also lost them all. However, he reminded me of a clever and useful solution: making the shareholders watch all the ticket purchases. Being interested in collecting all the money, they will be the most severe, most punctual, there will be no penny left behind (Assis, “A Semana" 02/09/1894) $)^{20}$.

The narrator admits at least some outbursts of geniality of his "stupid" servant, so much so that he consults him on that subject. Once more, Rodrigues' solution is simple but effective. The crônica implies that if the drivers and even the passengers committed small and profitable misconducts, it could not be compared to the earnings of companies that determine the price of tickets and the salaries of their employees, exploiting passengers and drivers alike. The loss was minimal contrasted to the benefits taken from the activity. The alleged dishonesty of those who worked so hard to get so little sounded like a small and well-deserved revenge.

Helen Caldwell compares the fictional Josés of Machado de Assis' literary work and affirms: "the traits typified by this name are those of an ordinary, conventional man,

20 "[...] O interesse é mais constante. José Rodrigues, a quem consultei sobre esta matéria, disse-me que isto de perder são os ônus do ofício; também a companhia de que ele tinha debêntures, perdeu-os todos. Mas lembrou-me um meio engenhoso e útil: incumbir os acionistas de vigiarem por seus próprios olhos a cobrança das passagens. Interessados em recolher todo o dinheiro, serão mais severos que ninguém, mais pontuais, não ficará vintém nem conto de réis da caixa."

RRASILIANA- Journal for Brazilian Studies. Vol. 4, n.2 (2016). ISSN 2245-4373. 
with his feet on the ground, a man of limited learning and limited imagination, an officious, wordy man, given to voicing the obvious or what generally passes for true. He is often a servant, or with a servile way about him, and frequently hypocritical." Specifically about José Rodrigues, Caldwell says he is:

one who discloses his nature in all its unspoiled simplicity. [...] He seems to represent a homely strain in the sophisticated columnist - his stupid, prosaic side, the man in the street as opposed to the poetphilosopher in the ivory tower, the body to the soul, Sancho Panza to Don Quixote - and there is often a strain of practical wisdom in his rambling conversations (Caldwell, 1960, p.44-50).

In fact, the servant-master opposition and José Rodrigues' "practical wisdom" appear to be a constant in "A Semana". However, Rodrigues is neither cynical nor, as I said, stupid. The negative impression of the servant is given to us by an unreliable narrator. In most cases, the interaction between the characters gives the idea that the hypothetical sophistication and superiority of the boss are so artificial that they cannot be sustained for more than a few lines. The practical and popular knowledge of the employee is much stronger and more coherent than the imaginative conjectures of the employer.

The questions brought up by the voices of the narrator and his servant express themes that were discussed not only by the writer but also by his contemporaries. As I already pointed out, their considerations are permeated by a class difference, which is present in their financial concerns (or in the lack of thereof) and in the way in which they interpret the context that surrounds them. The language used by José Rodrigues and his employer reflects these two different readings of the same situation. 
Amid the Revolta da Armada, when Rio de Janeiro was being bombed, the semanista preferred to weave some considerations on the verb "explode". In this regard, he stated that he imitates Molière and his cook: "I write, - I do not know if I mentioned this before, - using the language of my servant". José Rodrigues had never seen a bomb explode: "For him, everything pops, bursts, overflows. What he does is graduate the application of verbs, so that the popcorn never pops. Who taught him this, I do not know. Perhaps the milk of his mother." (Assis, "A Semana", 24/09/1893)21. The employee's words are highlighted again when the narrator talks about those who would profit despite or because of the bombing of the capital, from the glaziers who have much work ahead of them, to those who would take advantage of the attention focused on serious events to make particular emissions, which was illegal: "simply the credit, 'that lever of progress and civilization', as my servant says. Therefore, society will have found the way that it lost since the death of Feudalism. Starvation will starve. Nobody will beg, everyone will give." (Assis, "A Semana", 12/11/1893)22. The cook referenced in the crônica is Martine from the theatrical piece Les Femmes Savantes. Martine is fired for being "aggressive" to her mistress by an "ignorant solecism" and an "extremely rare lexical absurd". In the continuation of the plot, Martine is considered wiser than her employer, despite her language being reputed to be $\mathrm{bad}^{23}$. This relationship is very similar to the one between the narrator and his servant.

\footnotetext{
21 "Eu escrevo, — não sei se lhes disse isto alguma vez, — pela língua do meu criado". "Para ele tudo estala, rebenta, estoura. O que ele faz, é graduar a aplicação dos verbos, de modo que jamais a pipoca estoura. Quem lhe ensinou isto, não sei. Talvez o leite de sua mãe.”

22 “simplesmente no crédito, 'essa alavanca do progresso e da civilização', para falar como o meu criado. Isto posto, a sociedade terá achado o eixo que perdeu desde a morte do feudalismo. A fome morrerá de fome. Ninguém pedirá, todos darão."

${ }^{23}$ Molière, 2013. See, especially, Act II, scene VI.
}

3RASILIANA- Journal for Brazilian Studies. Vol. 4, n.2 (2016). ISSN 2245-4373. 
José Rodrigues is a voracious reader of newspapers and, more than that, an interpreter of the news read in the press, translating into his own language the content of the daily papers. When the character is lost before what he reads, the narrator treats him as stupid, ignorant etc. Notwithstanding, the servant's difficulty in understanding can be seen as a criticism of the inadequacy of the narratives that are presented in the press - including the Gazeta de Notícias. It is what seems to happen in one of the crônicas published in May of 1894, in which boss and servant discuss the Father Kneipp treatment ${ }^{24}$. This time, both of them read the newspaper. At first, the narrator affirms that if the German priest's water were miraculous, it would not need so many ads. Nevertheless, on second thought, he finds something interesting in the invention which "not only heals and resurrects but is also the freest medicine of this world. All that seems to cost some money is the clothing that is already made and appropriate; the rest is water, which God gives us. Little water" (Assis, "A Semana", 06/05/1894) ${ }^{25}$. The faithful José Rodrigues makes some cogitations about the issue to say "soulless water" would hardly give life to someone. The semanista asks him to explain what soulless water is:

- Sir, the soul of the water (forgive me for explaining that to you) is the grape. Put two or three fingers of red [wine], and drink it instead of getting into it; that is what I am telling you. The grocer around the corner could gladly [do it], and now we have this doctor Naipe [suit]... Naipe of what? Of hearts, most certainly. Copas [hearts] like they used to

\footnotetext{
${ }^{24}$ The German priest Sebastian Kneipp (1821-1897), creator of a group of therapeutical practices that uses especially hydrotherapy. About Kneipp and his theories, see: Baubérot, 2008.

25 "não só cura e ressuscita, como é a mais gratuita das farmácias deste mundo. Só o que parece custar algum dinheiro, é a roupa, que há já feita e apropriada; o mais é a água, que Deus dá. Água e pouca."
} 
paint in the old playing cards, which is what we now call copos [cups] drinking cups. ${ }^{26}$

As in other crônicas, the servant's attitude is extremely humble, apologizing even for teaching something to his "wise" boss. Rodrigues bases his opinion on the popular belief of using alcoholic beverages for medicinal purposes. We can assume Machado, through the two characters, was pointing out the advantages of popular wisdom compared to the new theories and medical practices emerged in the second half of the nineteenth century, since that was not the first time he ridiculed the "scientific" beliefs of the time.

There is the supposed confusion related to the "doctor"'s name, which is corrected by the cronista: the right one being Kneipp.

- Whatever, I have never cared about names unless they are Christian. For the grocer around the corner, as I was saying, could sell it pure, and make a profit; but he is conscientious, and puts some two fingers of soul in it, and that is what I drink every day. You know how healthy this servant of yours is. Water on the body of a man, on the skin, it causes malaria, sir; I had fevers, years ago, due for sure to a cold shower I was given in an entrudo. A shower must be short and warm, to

26 “- Senhor, a alma da água (perdoe-me vosmecê que lhe ensine isto) é a uva. Ponha-lhe dois ou três dedos do tinto, e beba-a, em vez de se meter nela; é o que lhe digo. O vendeiro da esquina podia muito bem, agora ainda aí esse doutor Naipe... Naipe de quê? há de ser copas, de certo. Copas como elas se pintavam nas cartas antigas, que eram o que chamamos copos - copos de beber.". There are two separate wordplays in the excerpt, both related to playing cards. The word naipe stands for a suit in a deck of cards, and its pronunciation is very similar to the German name Kneipp. Furthermore, copas is the hearts suit, whereas copos are [drinking] cups. 
clean what God loves, as long as it does not take away the substance, which is foremost... (Assis, "A Semana", 06/05/1894.) ${ }^{27}$

José Rodrigues' simplicity exposes the criticism to the scientific wave of those years. The difference between Kneipp's hydrotherapy and the grocer's water with soul was in the fact that the latter was more efficient and even more honest. Even the possible smartness of the grocer - who mixed water in the wine and, therefore, profited more - was wellknown to everyone, so nobody was deceived. Another possible interpretation is that the beliefs of José Rodrigues in the causes of diseases did not differ from faith in waterbased treatments. Once again, the ideas expressed in the crônica contradicted the hegemonic discourse and even the attention given by the Gazeta de Notícias to the (supposed) scientific novelties. In the week before that "A Semana", the newspaper published the last article in a series entitled "Kneipp Treatment", which was printed on the first page, attesting the effectiveness of the therapy. Through his fictional characters, Machado de Assis placed himself against what the Gazeta, the same daily paper that published his work, defended in its columns.

In the sequence, the servant - the "poor devil" - thinks about selling his debentures to his boss for an insignificant amount compared to how much he had lost. Rodrigues affirms that, since the cronista was "more sagacious" than him, he would find something in them, "even if it was a microbe - because the microbes (I must be sure of it), with the actual scientific progress, will feed us, instead of destroying us" (Assis, "A

27 “- Ou o que quer que seja, que a mim nunca me importaram nomes, desde que não sejam cristãos. Pois o vendeiro da esquina, como ia dizendo, podia muito bem vendê-la pura, e ganhava dinheiro; mas é consciencioso, põe-lhe uns dois dedos de alma, e é o que eu bebo todos os dias. Vosmecê sabe que saúde é a deste seu criado. Água no corpo de um homem, pelo lado de fora, isso dá maleitas, senhor; eu tive umas sezões, há muitos anos, que com certeza foram obra de um banho frio que me deram pelo entrudo. O banho deve ser pouco e morno, para a limpeza que Deus ama, contanto que nos não leve a sustância, que é o principal..."

RRASILIANA- Journal for Brazilian Studies. Vol. 4, n.2 (2016). ISSN 2245-4373. 
Semana", 23/12/1894)28. Tired of listening to his employee's meditations, the narrator orders him to bring water from the Carioca street fountain. "After less than half an hour, José Rodrigues came back to the house, without water and full of wonder. In the fountain, there was no water." Therefore, the inexpensive medication was not accessible. The semanista alleges to know his people, so he knew the recollection of the debentures had unsettled Rodrigues, "such was the confusion of words, the fumble of ideas". In his usual selfishness, the narrator says: "Which was the medicine that healed me, I do not know; maybe, it was seeing someone sicker than me" (Assis, "A Semana", 23/12/1894)29.

The servant's fumble of ideas shows up in another excerpt of that crônica, in which the narrator says: "This José Rodrigues is good, diligent, respectful, but his intellect limps, he is not crazy, but stupid. I do not say he is a donkey; a talking donkey would be smarter than him" (Assis, "A Semana", 23/12/1894)30. Boss and employee have an extensive dialog. Rodrigues affirms he is unable to understand the meaning of two ads found in the newspaper: "For rebel coughing, jaramacaru syrup'. 'For municipal intendant, Calisto José Paiva'. Which one of those two medicines is better? And what is this illness that I have never seen?", he asks. The narrator, once more, calls him a fool and explains the illnesses were two, so "It is clear both of them are good, one for rebel coughing, the other for municipal intendant." The servant inquires if that illness (municipal intendant) was similar to "neurasthenia", the ailment that the boss taught

\footnotetext{
28 "ainda que fosse um micróbio - porque os micróbios (ficasse eu certo disso), com os progressos da ciência em que vamos, ainda acabam alimentando a gente em vez de nos pôr a espinhela abaixo."

29 "Não havia passado meia hora, voltou José Rodrigues à casa, sem água, cheio de espanto. O chafariz não tinha água." /"tal era a confusão das palavras, a trapalhice das idéias." "Qual foi o remédio que me curou, não sei; talvez a vista de algum mais doente que eu."

30 “Este José Rodrigues é bom, é diligente, respeitoso, mas coxeia do intelecto, não que seja doido, mas é estúpido. Não digo burro; burro com fala seria mais inteligente que ele". Burro (donkey), in Brazilian Portuguese, is a synonym of stupid.
} 
him how to pronounce. "Or is municipal intendant something related to teeth? Boss, forgive me; I did not go to schools, I did not learn laws or medicine..." ${ }^{31}$. The narrator asks if he knows what a councilman is: the answer is affirmative. The boss states:

- For it is the same thing.

- The same thing? I understand; it is like espinhela caida that now we call anatomy or neurasthenia. Well, yes, sir. Intendant is the same as councilman. Does it heal with the Paiva from the ad? But if the Paiva is the medicine, as the boss says, I do not understand it applied to neurasthenia ou intendant...

- You are not well, José Rodrigues; go away.

- To be honest, well, well, I am not; I woke up with pain in my side, and I cannot breathe, and it is why I asked you which was better, the syrup or the Paiva. Maybe the Paiva is cheaper than the syrup. This of medicines, it is not because they are expensive... Sometimes the most expensive ones are good for nothing, and a cheap one heals very well. The health deserves everything. However, in the end, I do not mind the price. I will go with the Paiva... I mean, the newspaper also mentions some Canedo for the same illness... Is it not Canedo? Maybe the Canedo is cheaper than the Paiva.

31 “- Patrão, leio aqui estes dois anúncios: 'Para tosses rebeldes, xarope de jaramacaru'. 'Para intendente municipal, Calisto José Paiva'. Qual destes dois remédios é melhor? E que moléstia é essa que nunca vi?"/ "É claro que ambos são bons, um para tosses rebeldes, outro para intendente municipal."/ "Ou intendente será assim coisa de dentes?... O patrão me desculpe; eu não andei por escolas, não aprendi leis nem medicina..." 
- This is a question for the apothecary. Take what you can, but, before, do me a favor. Go see if I am at the Largo da Carioca. (Assis, "A Semana", 23/12/1894) $)^{32}$.

It is the first time in "A Semana" that we listen to José Rodrigues' voice. It is a timid, wobbly, submissive voice, but it also takes risks, doubts the cronista's statements. The employee is lost before the new institutions that, in practical terms, were not that new, they just had different names. His views, especially the political ones, are from below. The boss-narrator's position is also interesting: he does everything to keep his servant in an inferior condition and, more than that, to make him come across as a fool to the readers. The semanista presents himself as a highly-educated person who faces someone who does not understand anything about political events. Nevertheless, it is José Rodrigues' innocence that reveals the things most like they are. The narrator's position is comical: while he is trying to show his superiority to the readers, it becomes apparent that he does not completely comprehend the situation. Considering the idea of clinging to the past and despising the new, we must remember that the servant is sometimes an anchor to that safer time, far from modernity. Behind all this, there is still the criticism to the municipal elections, seen as an illness, and one that persisted.

\footnotetext{
32 “- Pois é a mesma coisa./ - A mesma coisa? Entendo; é como a espinhela caída que hoje se chama anatomia ou neurastenia. Pois, sim, senhor. Intendente é o mesmo que vereador. Cura-se então com o Paiva do anúncio? Mas se o Paiva é o remédio, conforme diz o patrão, não entendo que se aplique a neurastenia ou intendente.../ - Tu não estás bom, José Rodrigues; vai-te embora./ - Para dizer a minha verdade, bom, bom, não estou; amanheci com uma dor do lado, que não posso respirar, e é por isso que vim perguntar ao patrão se era melhor o xarope, se o Paiva. Talvez o Paiva seja mais barato que o xarope. Isto de remédios, não é o serem mais caros... Às vezes os mais caros não prestam para nada, e um de pouco preço cura que faz gosto. Mas, enfim, não faço questão de preço. A saúde merece tudo. Vou ao Paiva... isto é, o jornal fala também de um Canedo, para a mesma moléstia... Não é Canedo que se diz? Talvez o Canedo seja mais barato que o Paiva./ - Isto é cousa que só à vista das contas do boticário. Toma o que puderes; mas, antes disso, faz-me um favor. Vai ver se estou no Largo da Carioca."
} 
I would argue that Machado de Assis probably creates José Rodrigues to emphasize the characteristics of his narrator. Perhaps that is why most of José Rodrigues' appearances were between 1893 and 1894, the first years of the series. This procedure was not unprecedented in his crônicas. In "Bons Dias!" there was Pancrácio, the narrator's "moleque" (lad), meaning his young slave ${ }^{33}$. However, the servant of "A Semana" does not seem to be just a "stair" for the narrator. His recurrence in the series shows that Machado created a character with its own characteristics and tried to give it coherence. Rodrigues impersonates an economically deprived layer of society and, therefore, represents a majority. He could be considered a synthesis of the poor population of Rio de Janeiro, who also faced the failed promises of improvements that would come with the new political regime. Also, he faces the attempt to control and modify customs, which were being modernized by force.

In 1895, only one crônica mentioned the employee. As usual, he is shown in opposition to his boss: "Some people think and sweat; I, when I sweat, do not think." This task was left to José Rodrigues, who "always thinks, although it is the opposite of what pleases me; for example, he brushes my hat backward. Naturally, I scold him." The reprimand was to make the servant stop thinking once in his life. Rodrigues' answer is: "- Forgive me, but the thought is an influence that comes from the stars; no one can go against them". The employer remains silent, claiming: "Nowadays, to have a servant who thinks but earns little is such a rare fruit that it is not worth discussing the

\footnotetext{
${ }^{33}$ In this text, the historian affirms: "Machado was creating from a particular historical experience, producing a text of self-enlightenment and action." ["Machado estava criando a partir de uma experiência histórica particular, produzindo um texto de auto-esclarecimento e de atuação.”]. Chalhoub, 2006, p.102.
} 
origin of ideas with him. It is better to change the hat than the salary" (Assis, "A Semana", 24/03/1895). ${ }^{34}$

The last reference to José Rodrigues happens in June 1896. The crônica invites the readers to escape from Rio de Janeiro, which, in the narrator-boss' words, had become a "Babylon", arousing fear in him:

I am afraid of everything. My old servant José Rodrigues... (Do you remember José Rodrigues?)... is not well, he has seizures, chest pain, nausea; to me, it is the heart. If I were not afraid of the pharmacy giving him the wrong poison, as it happened this week, I would have had him examined a long time ago. [...] I do not know... Poor José Rodrigues! He is a great sample of human vicissitudes.

Hardly knowing how to sign his name, he won a million in the Encilhamento, and when he was beginning to learn how to spell, found himself with three thousand réis.

- 'Oh, boss!', he told me once, 'I should never have gotten myself into spellings; a B more or less is not what makes a happy man'. (Assis, "A Semana", 28/06/1896) ${ }^{35}$.

\footnotetext{
34 "Há quem pense, transpirando; eu, quando transpiro, não penso."/ "pensa sempre, embora seja o contrário do que me é agradável; por exemplo, escova-me o chapéu às avessas. Naturalmente, ralho."/ "— Há de perdoar, mas o pensamento é influência que vem dos astros; ninguém pode ir contra eles"/ "Nos dias que correm, ter um criado que pense barato, é tão rara fruta, que não vale a pena discutir com ele a origem das idéias. Antes mudar de chapéu que de ordenado."

35 “Temo tudo. O meu velho criado José Rodrigues... (Lembram-se do José Rodrigues?)... não anda bom, padece de tonteiras, dores de peito, ânsias; para mim, está cardíaco. Se não temesse que a farmácia aviasse um veneno por outro, como ainda esta semana sucedeu, há muito que o teria feito examinar. [...] Não sei... Pobre José Rodrigues! É um grande exemplo das vicissitudes humanas. Mal sabendo assinar o nome, ganhou um milhão no encilhamento, e quando começava a aprender ortografia, achou-se com três mil réis./ - Ai, patrão! dizia-me ele uma vez, eu nunca me devia ter metido em ortografias; um B de mais ou de menos não é que faz um homem feliz.”
} 
The servant is sick and, although showing some compassion, his boss does not seem too keen to seek a cure for the infirm man. The entire crônica talked about death. Suicides, battles, diseases. "It looks like a wind of death is in the air." We can imagine that Rodrigues' death was coming. Subject to vicissitudes, the employee regrets having "gotten into orthographies" (Assis, "A Semana", 28/06/1896)36, which just complicated his existence. He blames narratives and language for his suffering. Throughout "A Semana", José Rodrigues split his worries between finances and health. His incomprehension before the current speech, most of it coming from newspapers, points to Machado de Assis' criticism of the inadequacy of these narratives to account for a much wider and diverse reality than assumed by their supporters. The scientific language (which in this crônica is compared to the literary language, in detriment of the former) used to direct and control the daily life is not capable of reporting what actually happens in the city. In an attempt to force the sanitization of practices and beliefs, many Josés Rodrigues suffered, hit by something alien to their experience. Others, like his boss, understood even less, preferring to embrace the progress that, in that situation, suited them better.

\section{References}

Gazeta de Notícias, Rio de Janeiro (1892-1897).

Assis, Machado de. 1996. A Semana: crônicas (1892-1893). Edited by John Gledson. São Paulo: Hucitec.

\footnotetext{
36 "parece que anda um vento de morte no ar"/ "metido em ortografias".
} 
Baubérot, Arnaud. 2008. “Un projet de Réforme Hygiénique des modes de vie: naturistes et végétariens à la Belle Époque", French Politics, Culture \& Society, Vol. 26 (Winter), no. 3 .

Betella, Gabriela Kvacek. 2007. Narradores de Machado de Assis: a seriedade enganosa do Conselheiro (Esaú e Jacó e Memorial de Aires) e a simulada displicência das crônicas (Bons Dias! e A Semana). São Paulo: Edusp/Nankin.

Caldwell, Helen. 1960. The Brazilian Othello of Machado de Assis: a study of Dom Casmurro. Berkeley and Los Angeles: University of California Press.

Cardozo de Souza, Ana Paula. 2015. Machado de Assis e a República de "A Semana": literatura, imprensa e práticas populares (1892-1897). MA thesis. UNICAMP.

Chalhoub, Sidney. 2006. Cidade Febril: cortiços e epidemias na Corte Imperial. São Paulo: Companhia das Letras.

Gerson, Brasil. 2000. História das Ruas do Rio: e da sua liderança na história política do Brasil. 5ed. Rio de Janeiro: Editora Lacerda.

Gledson, John. 2006. Por um novo Machado de Assis, ensaios. São Paulo: Companhia das Letras.

Grimal, Pierre. 2005. Dicionário da Mitologia Grega e Romana. Trans. Victor Jabouille. Rio de Janeiro: Bertrand Brasil.

Lima, Mariana da Silva. 2012. Machado de Assis, um cronista na Primeira Republica - Visões do Brasil na série "A semana" ) Ph.D. thesis. UFRJ.

Molière, The Learned Women. 2013. Trans. Charles Wall. Project Gutenberg Ebook.

Pereira, Leonardo M. 2004. O Carnaval das Letras: literatura e folia no Rio de Janeiro do século XIX. Campinas: Editora da Unicamp.

Ramos, Ana Flávia C. 2010. As máscaras de Lélio: ficção e realidade nas "Balas de Estalo" de Machado de Assis. Ph.D. thesis. UNICAMP.

3RASILIANA- Journal for Brazilian Studies. Vol. 4, n.2 (2016). ISSN 2245-4373. 